\title{
Ligand Control of the Metal Coordination Sphere: Structures, Reactivity and Catalysis
}

\author{
Andreas A. Danopoulos ${ }^{1,2 *}$ and Pierre Braunstein ${ }^{1 *}$ \\ ${ }^{1}$ Laboratoire de Chimie de Coordination, Institut de Chimie (UMR 7177 CNRS), Université de Strasbourg, 4 rue Blaise Pascal, \\ 67081 Strasbourg Cedex - France \\ ${ }^{2}$ Institute for Advanced Study (USIAS), Université de Strasbourg, 5 allée du Général Rouvillois, 67083 Strasbourg Cedex - France \\ e-mail: danopoulos@unistra.fr - braunstein@unistra.fr \\ * Corresponding author
}

Dedicated to the memory of Yves Chauvin, a most remarkable and visionary man and scientist, with gratitude for our scientific and non-scientific conversations and a very fruitful and enjoyable collaboration.

\begin{abstract}
Two major aspects of coordination/organometallic chemistry are discussed in this article: (i) the use of functional chelating ligands to stabilize metal complexes while allowing easy stereodifferentiation within the coordination sphere and (ii) the choice of suitable ligands to stabilize challenging 'underligated' metal complexes with electronically highly unsaturated metal centres, thus potentially displaying unusual reactivity. In both cases, the relevance to homogeneous catalysis will be discussed.
\end{abstract}

Résumé - Contrôle de la sphère de coordination des métaux par les ligands : structures, réactivité et catalyse - Deux aspects majeurs de la chimie de coordination/organométallique sont discutés dans cet article : d'une part, l'utilisation de ligands chélatants fonctionnels pour stabiliser des complexes métalliques en permettant une différenciation stéréoélectronique aisée au sein de la sphère de coordination et, d'autre part, la sélection de ligands adaptés à la stabilisation de complexes métalliques sous-coordinés dont les centres métalliques sont hautement insaturés électroniquement et donc potentiellement le siège d'une réactivité inhabituelle. Dans les deux cas, nous évoquerons la pertinence de ces approches en catalyse homogène.

\section{INTRODUCTION}

The synthesis, coordination chemistry and catalytic applications of functional phosphine-type ligands have represented a very fast growing field of research during the past 30 years and the diversity of donor groups that can thus be associated with the phosphorus donor opens unlimited possibilities. The chemically different nature of the functions available for coordination to metal centres immediately leads to consider the intrinsic properties of the resulting bonds and their consequences on the nature of the interactions between the metal(s) and other ligands present in the coordination sphere. This is illustrated in Scheme 1 with the simple case of a square-planar metal complex. Even if the ligands A and B are chemically the same (e.g. two chlorido or two methyl ligands), their reactivity will not be identical because of the stereochemically-different environment generated by the chelating functional phosphine ligand. This would not be the case in the presence of a symmetrical $P, P$ or a $Z, Z$ chelate with identical donor groups. Hybrid ligands thus represent a straightforward stereoelectronic differentiation tool within the metal coordination sphere, allowing selective reactivity and fine-tuning of the catalytic properties of metal complexes, as exemplified in the case of ethylene oligomerization $[1,2]$. 


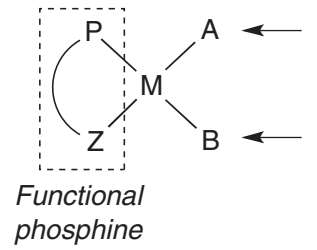

Scheme 1

Stereochemical differentiation in a metal coordination sphere resulting from chelation of a functional phosphine.

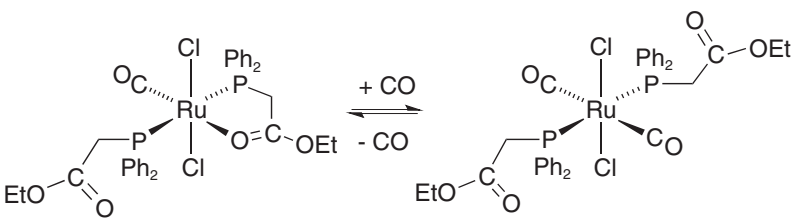

Scheme 2

Reversible binding of $\mathrm{CO}$ resulting from the opening and closing of the metal-oxygen dative bond involving the $\mathrm{P}, \mathrm{O}$ chelate [24].
Ethylene, propylene and butenes are in increasing demand [3-13]. Ethylene alone is at the origin of $c a .30 \%$ of the products originating from the petrochemical industry. Among the $\alpha$-olefins in the range $\mathrm{C}_{4}-\mathrm{C}_{20}$, those with shorter chain lengths $\left(\mathrm{C}_{4}-\mathrm{C}_{8}\right)$ enjoy a rapidly expanding market owing to their applications as comonomers for the production of high density polyethylene and linear low density polyethylene and as intermediates in the production of oxo alcohols, hexyl- and octyl-mercaptans, amines, etc. Other linear $\alpha$-olefins find applications e.g. for the fabrication of lubricants $\left(\mathrm{C}_{10}\right)$, biodegradable detergents $\left(\mathrm{C}_{10}, \mathrm{C}_{12}, \mathrm{C}_{14}\right)$, surfactants and lubricant additives $\left(\mathrm{C}_{12}-\mathrm{C}_{20}\right)$ and many other useful chemicals. These features explain the continuing interest in both academia and industry for this research area [14-19].

The first part of this contribution will illustrate some of the work we carried out with metal complexes containing $\mathrm{P}, \mathrm{O}-, \mathrm{P}, \mathrm{N}-$, and N,O-type ligands relevant to ethylene oligomerization. This topic was selected because it corresponds to the starting points of our collaboration with Yves Chauvin and his group in the mid-90s. The second part deals with very recent developments concerning the stereoelectronic stabilization of 'underligated' metal complexes, a concept that illustrates a change of paradigm with respect to the classical 18 valence electron rule. Underligated complexes attract a rapidly increasing interest because of their often unusual features and reactivity and relevance to catalysis owing to the electronic unsaturation of their coordination sphere.

\section{METAL COMPLEXES WITH FUNCTIONAL CHELATING LIGANDS}

\subsection{Metal Complexes with P,O-Type Ligands}

In our first publication on transition metal complexes with functional phosphines, we described the coordination of the phosphino-ester ligand $\mathrm{Ph}_{2} \mathrm{PCH}_{2} \mathrm{C}(\mathrm{O}) \mathrm{OEt}$ to various transition metal centres [20, 21]. In the case of $\mathrm{Rh}(\mathrm{III})$ and $\operatorname{Ir}(\mathrm{III})$, octahedral trihalide complexes containing two such ligands were characterized, in which one of them is terminally $\mathrm{P}$-bound to the metal whereas the other acts as a $\mathrm{P}, \mathrm{O}$ chelate. It was found by ${ }^{1} \mathrm{H}$ and ${ }^{31} \mathrm{P}\left\{{ }^{1} \mathrm{H}\right\}$ variabletemperature NMR spectroscopy that a dynamic behaviour was taking place in the $\mathrm{Rh}$ (III) complex, but not in the $\operatorname{Ir}(\mathrm{III})$ complex, that led the two ligands to exchange their role above coalescence temperature. This dynamic behaviour, which involves opening and closing of the metal-oxygen bond of the P,O chelate, became shortly after known as hemilabile behaviour [22, 23]. Related observations were made with $\mathrm{Ru}(\mathrm{II})$ complexes and applied to the reversible binding of carbon monoxide under ambient conditions (Scheme 2) [24].

Similarly to the phosphino-ester ligand $\mathrm{Ph}_{2} \mathrm{PCH}_{2} \mathrm{C}(\mathrm{O}) \mathrm{OEt}$, the phosphino-ketone $\mathrm{Ph}_{2} \mathrm{PCH}_{2} \mathrm{C}(\mathrm{O}) \mathrm{Ph}$ was found to chelate transition metals and its easy and modular synthesis prompted numerous studies in coordination chemistry [25]. It was rapidly found that when this ligand is coordinated to a transition metal, either $\kappa^{1}-P$ or $\kappa^{2}-P, O$, its deprotonation readily affords complexes containing a P,O-chelating phosphino-enolate ligand $\left[\mathrm{Ph}_{2} \mathrm{PCH} \cdots \mathrm{C}(\cdots \mathrm{O}) \mathrm{Ph}\right]^{-}$, weak bases being sufficient as a result of the enhanced acidity of the $\mathrm{PCH}_{2}$ protons upon coordination [26]. This observation appeared very promising, in particular in view of the remarkable properties of nickel complexes containing such phosphino-enolate and related ligands in catalytic ethylene oligomerization, which form the basis of the industrial Shell Higher Olefin Process (SHOP) [27-49]. This process does not require any cocatalyst and leads to linear $\alpha$-olefins with remarkable selectivity. Furthermore, access to a diversity of transition metal complexes containing phosphino-enolates and related ligands opens interesting perspectives since the reaction pathway leading to the SHOP-type

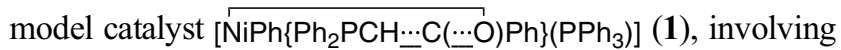
oxidative-addition of a $\mathrm{P}$-Ph bond of the corresponding $\beta$-keto phosphorus ylid $\mathrm{Ph}_{3} \mathrm{PCH}=\mathrm{C}(\mathrm{O}) \mathrm{Ph}$ across $\mathrm{Ni}(0)$, only works with $\mathrm{Ni}(0)$ (Scheme 3). These considerations formed the basis of stimulating discussions with Yves Chauvin at the Institut Français du Pétrole, Rueil-Malmaison, which initiated a 


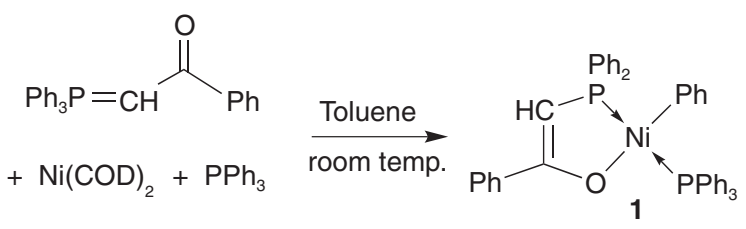

Scheme 3

Typical synthesis of a SHOP-type ethylene oligomerization pre-catalyst.

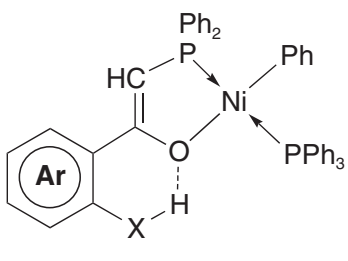

$\mathrm{X}=\mathrm{O}, \mathrm{NMe}, \mathrm{NPh}$

2

Scheme 4

Intramolecular hydrogen bonding between the ortho-substituent in the aryl group and the oxygen atom of the P,O-chelate.

fruitful collaboration, still very active more than 20 years later. In our first joint paper, we examined the influence of a $\mathrm{OH}$ or NHR ortho-substituent in the aryl group Ar of Ni(II) complexes of type 2 (Scheme 4) on their catalytic properties toward ethylene oligomerization [47]. It was found that $\mathrm{H}$-bonding interactions between this substituent and the enolate $\mathrm{O}$ atom resulted in a remarkable shift of the molecular mass distribution towards the highly desirable shorter chains oligomers.

These very encouraging results on the influence of aryl substituents on catalytically relevant intramolecular $\mathrm{H}$-bonding interactions prompted further studies. Thus, when the ortho-OH group on the ring Ar was replaced with a methoxy substituent in:

$$
\left[\mathrm{NiPh}\left\{\mathrm{Ph}_{2} \mathrm{PCH} \stackrel{-\cdots \mathrm{C}(\cdots \mathrm{O})}{ }\left(\mathrm{o}-\mathrm{MeO}-\mathrm{C}_{6} \mathrm{H}_{4}\right)\right\}\left(\mathrm{PPh}_{3}\right)\right]
$$

it was found by X-ray diffraction that the oxygen atom of the ether group is involved in a non-classical interaction with the hydrogen atom $\mathrm{H}^{\mathrm{a}}$ of the $\mathrm{C}-H$ group $\alpha$ to the phosphorus atom (Scheme 5). Furthermore, the hydrogen atom $\mathrm{H}^{\mathrm{b}}$ in the $o^{\prime}$ - position in $\mathbf{A r}$ is involved in another non-classical intramolecular hydrogen bonding interaction with the enolate oxygen atom $(2.34 \AA)$ and in a $\mathrm{C}-\mathrm{H}-\pi$ interaction with one of the phenyl rings of the $\mathrm{PPh}_{3}$ ligand ( $2.74 \AA$ from its centroid) [48]. The contrasting orientations of the $o-\mathrm{C}_{6} \mathrm{H}_{4} \mathrm{XH}$ and $o-\mathrm{C}_{6} \mathrm{H}_{4} \mathrm{OMe}$ aromatic cycles in $\mathbf{2}$ and $\mathbf{3}$, respectively, and the associated $\mathrm{H}$-bonding behaviour of the P,O ligand,
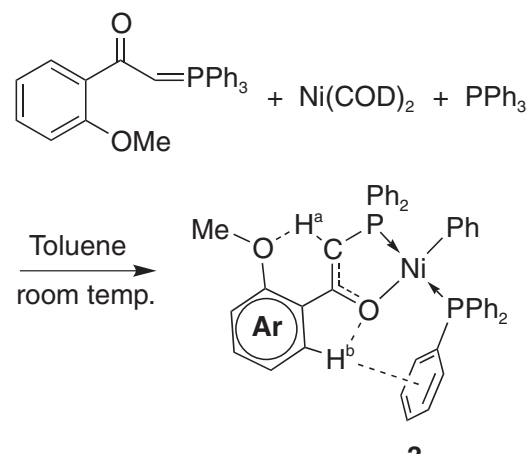

3

\section{Scheme 5}

Non-classical intramolecular hydrogen bonding and C-H- $\pi$ interactions involving the $\mathrm{P}, \mathrm{O}$-chelate.

which functions as acceptor in the former and both a donor and an acceptor in the latter, are noteworthy and emphasize the need for detailed structural investigations to identify the occurrence and consequences of subtle substituent effects.

These results triggered a theoretical structure-reactivity investigation of ethylene insertion into nickel-alkyl bonds [49]. The activation energy of the olefin insertion into nickel-alkyl bonds (i.e. alkyl migration) in a series of square-planar $\mathrm{Ni}(\mathrm{II})$ complexes of formula $\left[\mathrm{Ni}\left(\mathrm{X}^{\wedge} \mathrm{Y}\right)\right.$ (ethyl) (ethylene)], where $\mathrm{X}^{\wedge} \mathrm{Y}$ is a anionic bidentate ligand, was calculated by DFT methods. Where $\mathrm{X} \neq \mathrm{Y}$, the reactions of the two possible isomers have been compared and it was found that when one of the coordinating groups exerts a Weak Trans Influence (WTI) and the other a Strong Trans Influence (STI), as in the case of a phosphino-enolate $\mathrm{P}^{\wedge} \mathrm{O}$ ligand, one of the two isomers has an activation energy for olefin insertion significantly lower than that of the reaction of complexes with symmetrical bidentate ligands, either "WTI^WTI" or "STI^STI" [49].

The coordinated anionic $\mathrm{P}, \mathrm{O}-$ ligands $\left[\mathrm{Ph}_{2} \mathrm{PCH} \cdots \mathrm{C}(\cdots \mathrm{O}) \mathrm{Ph}\right]^{-}$ and $\left[\mathrm{Ph}_{2} \mathrm{PCH} \cdots \mathrm{C}(\cdots \mathrm{O}) \mathrm{OEt}\right]^{-}$were shown to carry significant electronic density at the $\alpha-\mathrm{PCH}$ carbon and this was evidenced by reactions with a number of organic and inorganic electrophiles [26]. A remarkably facile reversible binding reaction of $\mathrm{CO}_{2}$ by a $\mathrm{Pd}(\mathrm{II})$ complex under ambient conditions was discovered and its application to the catalytic telomerization of butadiene with $\mathrm{CO}_{2}$ [50, 51], and carbon-carbon bond formation by insertion of organic isocyanates $\mathrm{RN}=\mathrm{C}=\mathrm{O}$ into the $\alpha-\mathrm{PC}-H$ bond [52] were some of the outcome of these investigations. Extensions to isoelectronic or closely related metalloligands demonstrated the potential of these often air-stable but reactive systems $[26,53]$. Furthermore, reactions with metal electrophiles provided novel rational entries into homo- and heterodinuclear chemistry [26]. 
<smiles>CC1(C)COc2c1n1p2[C@@](C)(P)[N+]1(Cl)Cl</smiles><smiles></smiles>

$\mathrm{R}^{1}=\mathrm{Ph}, \mathrm{R}^{2}=\mathrm{H}$

$\mathrm{R}^{1}=\mathrm{CH}_{3}, \mathrm{R}^{2}=\mathrm{H}$

$\mathrm{R}^{1}=\mathrm{R}^{2}=\mathrm{CH}_{3}$

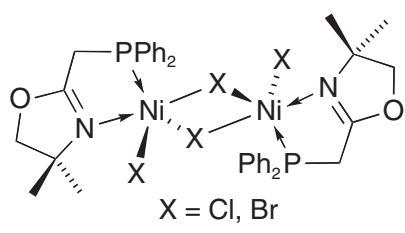<smiles></smiles><smiles>C[C@@H]1COC2=[N+]1[C@](C)(Cl)OP13(Oc4ccccc4-c4ccccc41)[N+](Cl)(Cl)[N+]23C</smiles><smiles></smiles>

Scheme 6

Various oxazoline- and pyridine-based P,N-type $\mathrm{Ni}(\mathrm{II})$ complexes, with chelate ring sizes ranging from 5 to 7 , applied to catalytic ethylene oligomerization [2].

\subsection{Metal Complexes with P,N-Type Ligands}

In the course of our studies - of which many were performed in collaboration with IFP Energies nouvelles - on the coordination properties of heterobidentate $\mathrm{P}, \mathrm{N}$-type ligands in relation to the catalytic properties of their nickel(II) complexes [2], the structures of numerous diamagnetic and paramagnetic complexes have been established by X-ray diffraction, which were often unpredictable in terms of metal coordination geometry and nuclearity (Scheme 6).

These investigations led i.a. to the finding that in the solid state, a microcrystalline sample of the green tetranuclear complex 4 could be transformed under pressure into its red mononuclear component 5 (Scheme 7) [54].

In other cases, different crystallisation temperatures could result in the formation of either mono- (6) or di-nuclear (7) complexes (Scheme 8) $[55,56]$. The influence of the chelating ligands on activity, selectivity and catalyst lifetime was investigated while keeping the amount of cocatalysts to the minimum required. Complex 6 has been evaluated as precatalyst in the oligomerization of ethylene, with $\mathrm{AlEtCl}_{2}$ or MAO as cocatalyst, or propylene, with MAO as cocatalyst. With only 2 equiv. of $\mathrm{AlEtCl}_{2}$, it was highly selective for the formation of ethylene dimers (up to 96\%) and with propylene, the selectivity for $\mathrm{C} 6$ products was higher than $98.5 \%$ [55].

These examples serve again to illustrate the importance of a full structural characterization of pre-catalysts in order to be in a position to draw meaningful structure-properties relationships.

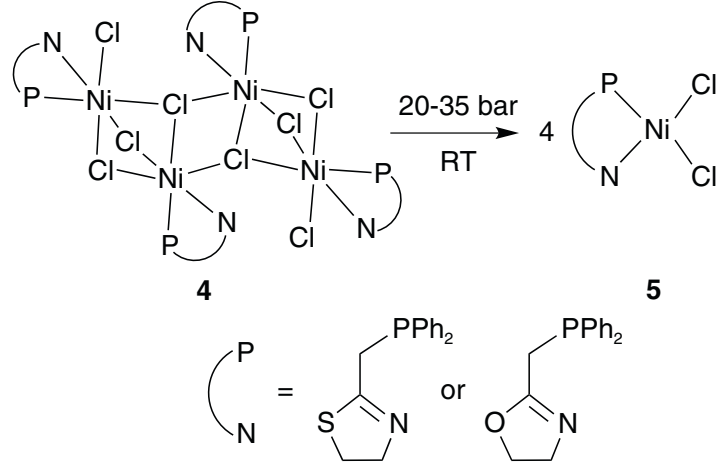

Scheme 7

Effect of pressure on complex nuclearity: conversion of a microcrystalline sample of the Ni(II) complex $\mathbf{4}$ into $\mathbf{5}$ under pressure in the solid state [54].

\subsection{Metal Complexes with N,O-Type Ligands}

Extending our studies of $\mathrm{Ni}$ (II) complexes with P,O- or $\mathrm{P}, \mathrm{N}$ - to $\mathrm{N}, \mathrm{O}$-type heterofunctional chelates also provided interesting findings. We focused on oxazolinyl- and pyridinyl-alcohols and - alcoholates as ligands and a range of polynuclear complexes with unexpected nuclearities and structures could be characterized (Scheme 9). The ability of the alcoholate oxygen to bridge between two or three metal centres plays a critical role and accounts for the isolation of a number of coordination clusters. 


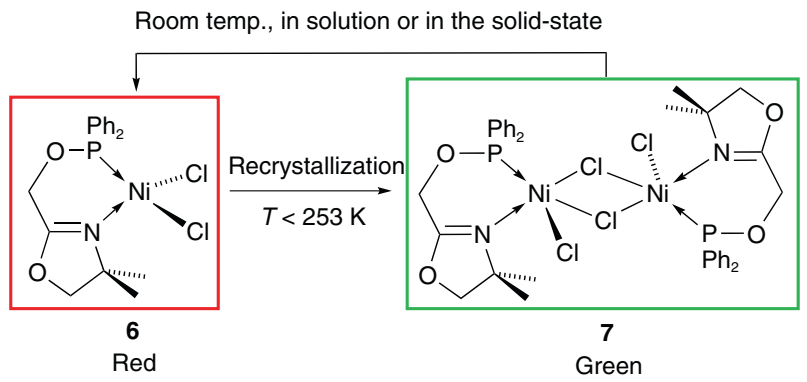

Scheme 8

Influence of the crystallization temperature on the nuclearity of the complex $[55,56]$.

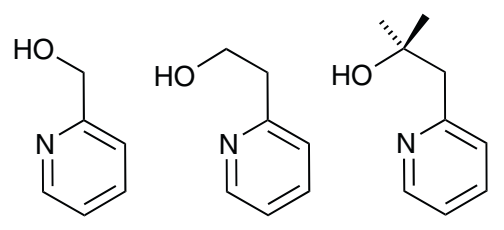

Scheme 9

Examples of pyridinyl-alcohols with different spacers between the heterocycle and the alcohol function investigated as ligands in $\mathrm{Ni}(\mathrm{II})$ complexes.

In particular, complexes with cubane-type structures could be structurally characterized, as well as higher nuclearity complexes constituted of assembled (incomplete) cubane units such as the octanuclear complex $\left.\left[\mathrm{Ni}\left(\mathrm{PyCH}_{2} \mathrm{O}\right)\right]_{3}\left(\mu_{2}-\mathrm{OCH}_{2} \mathrm{Py}\right)_{3}\left(\mu_{3}-\mathrm{OH}\right)\left(\mu_{5}-\mathrm{Na}\right)_{3}\left[\widetilde{\mathrm{Ni}\left(\mathrm{PyCH}_{2} \mathrm{O}\right.}\right)_{3}\right] \mathrm{Cl}$

(Fig. 1) [57-61].

Many of these polynuclear complexes turned out to have interesting magnetic properties and some behave as single molecule magnets [57-61].

Polynuclear metal architectures held together by coordination bonds or by direct metal-metal bonds may be considered as models to heterogeneous catalytic sites but can also serve as molecular precursors to nanosized heterogeneous particles. This is particularly useful in the case of heterometallic systems, where cooperativity and synergistic effects may arise [62]. Such compounds may also serve as reservoirs of lower nuclearity, or even underligated (see below), mononuclear, catalytically active fragments. These fundamental questions clearly deserve further investigations.

In conclusion to this section, it is clear that the diversity of heterobidentate ligands available offers an unlimited playground for transition metal coordination chemistry. In the course of systematic and rational approaches to fine-tune

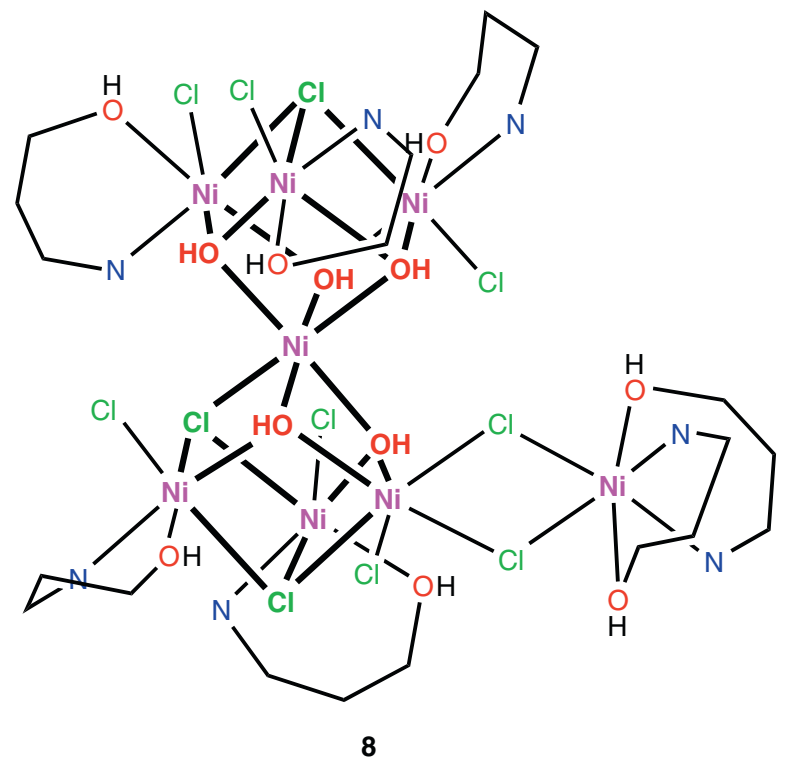

Figure 1

The $\mathrm{Ni}_{8}$ complex 8 containing cubane-type structural subunits [61].

the coordination sphere of a transition metal ion and thus the chemical and/or physical properties of its complexes, unexpected results may occur which open the way to new ideas and unanticipated developments; the role of serendipity should not be underestimated [63].

\section{UNDERLIGATED METAL COMPLEXES}

The renewed interest in the catalytic applications of 'base metals' (e.g. $\mathrm{Co}, \mathrm{Fe}, \mathrm{Ni}$ ), which fulfil to a certain extent green environmental criteria, drives the re-investigation of their coordination chemistry and the catalytic potential of well defined reactive complexes. In this respect, the paradigm that accompanied and guided organometallic chemistry with strong-field $\sigma$-donor and $\pi$-acceptor ligands since the Wilkinson years, viz. the 18 electron rule, predicting high stability in complexes with 18 valence electrons has to be abandoned to reach the realm of coordinative and electronic unsaturation in 'underligated', reactive complexes. With the expectation that a number of ligands and thus a valence electron count lower than usual will be associated with enhanced reactivity and catalytic properties, we have investigated, since 2010, the synthesis and properties of 'underligated' metal complexes of $\mathrm{Fe}, \mathrm{Co}$ and $\mathrm{Cr}$ stabilized by $\mathrm{N}-$ Heterocyclic Carbene ligands (NHC).

The approach was based on the use of bulky NHC as a means of supporting homoleptic and heteroleptic 


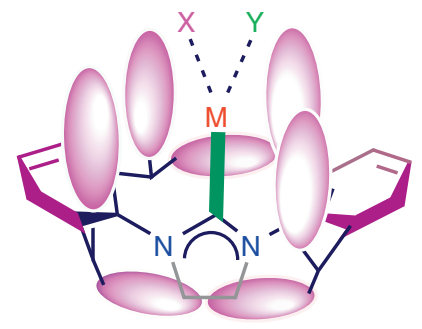

Figure 2

The NHC 'cavity' targeted to support 'underligation'.

underligated structures. The NHC have versatile and tuneable electronic properties (strong $\sigma$-donors, but occasionally accepting or donating $\pi$-electron density from or to the metal). Hence, compared to the strongly $\sigma$ - and $\pi$-donating amido-, alkoxo- and nacnac- (anionic bidentate ligands derived from 1,3-diketimines) co-ligands, NHC should lead to 'genuine' electronically unsaturated metal centres, the stability, bonding behaviour and reactivity of which under these conditions are not predictable. Compared to other bulky ligands (amido, terphenyl etc.), NHC offer easier and diverse steric tuning options leading to concave metal nesting 'pockets' (Fig. 2).

In this respect, the bulky ligands IPr (diisopropylphenyl substituents on the imidazole $\mathrm{N}$ atoms) and IMes (with mesityl substituents at $\mathrm{N}$ ), and the sterically relevant $\mathrm{SIPr}$ and SIMes (with a saturated heterocycle backbone), provide similar bulk and space organization to the bulky terphenyls developed by $\mathrm{Ni}$ and Power [64], although the latter are anionic and the NHC are neutral ligands.

Furthermore, underligated $3 \mathrm{~d}$ metal complexes are expected to show weak ligand fields with the following implications:

- open-shell energetically close-lying electronic states;

- non-covalent interactions frequently becoming functional in the stabilization of structural motifs;

- common occurrence of unusual oxidation states;

- control of the stoichiometric or catalytic reactivity by metal-centred or -generated paramagnetic intermediates;

- stabilization of metal-ligand multiple bonds with $3 \mathrm{~d}^{n}$ $2<n<10$ electron counts;

- spin crossovers during chemical reactions;

- unusual magnetic properties related to spin-orbit coupling and anisotropy.

All these characteristics set the scene for novel structures and reactivities in functional complexes.

A convenient entry into the synthetically useful 3-coordinate complexes of $\mathrm{Fe}^{\mathrm{II}}$ and $\mathrm{Co}^{\mathrm{II}}$ with high potential for mild and selective derivatization was the discovery of the aminolysis of $\left[\mathrm{M}\left\{\mathrm{N}\left(\mathrm{SiMe}_{3}\right)_{2}\right\}_{2}\right]_{2} \mathrm{M}=\mathrm{Fe}, \mathrm{Co}$, with bulky imidazol(in)ium halides $[(\mathrm{NHC}) \mathrm{H}] \mathrm{Cl}$,

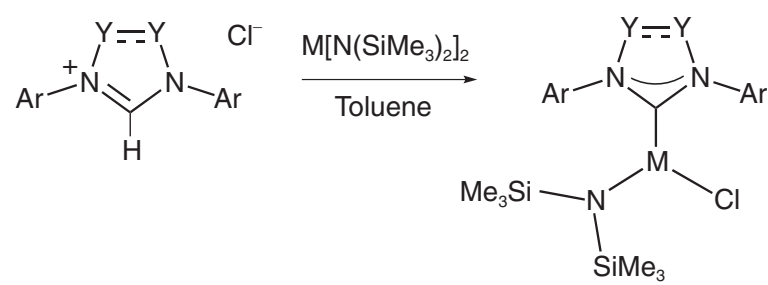

$\mathrm{Ar}=\mathrm{DiPP}: \mathrm{Y}=\mathrm{CH}, \mathbf{9} ; \mathrm{Y}=\mathrm{CH}_{2}, \mathbf{1 0}$

$\mathrm{Ar}=$ Mes: $\mathrm{Y}=\mathrm{CH}, 11 ; \mathrm{Y}=\mathrm{CH}_{2}, 12$

Scheme 10

Aminolysis of $\left[\mathrm{Fe}\left\{\mathrm{N}\left(\mathrm{SiMe}_{3}\right)_{2}\right\}_{2}\right]_{2}$ by imidazol(in)ium chlorides to give three-coordinate complexes; $\left[\mathrm{Co}\left\{\mathrm{N}\left(\mathrm{SiMe}_{3}\right)_{2}\right\}_{2}\right]_{2}$ reacts analogously.

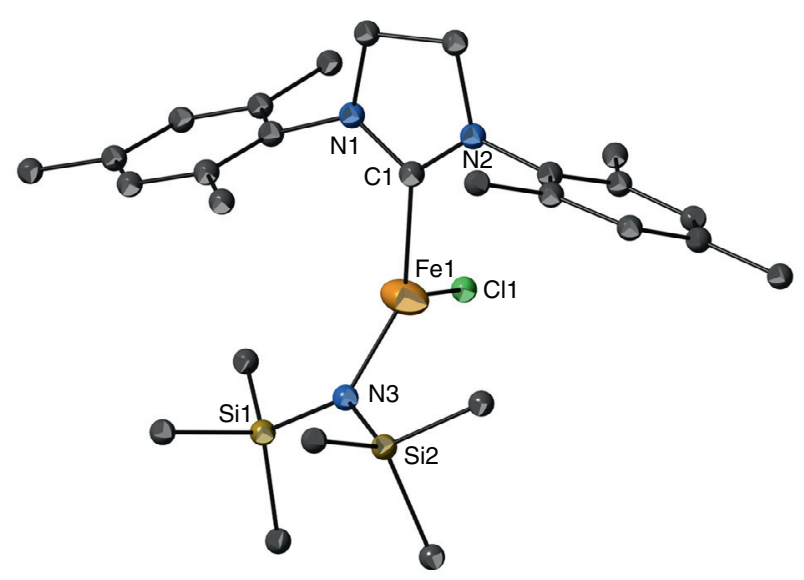

Figure 3

The structure of the $\mathrm{Fe}^{\mathrm{II}}$ complex $\mathbf{1 2}$

i.e. $[(\mathrm{S}) \mathrm{IPrH}] \mathrm{Cl},[(\mathrm{S}) \mathrm{IMesH}] \mathrm{Cl}$ ( $\mathrm{S}$ for saturated) and the isolation of $\left[\mathrm{M}(\mathrm{NHC})\left\{\mathrm{N}\left(\mathrm{SiMe}_{3}\right)_{2}\right\} \mathrm{Cl}\right]$ complexes (Scheme 10) $[65,66]$. The method was recently extended to $\left[\mathrm{M}\left\{\mathrm{N}\left(\mathrm{SiMe}_{2} \mathrm{Ph}\right)_{2}\right\}_{2}\right]_{2}, \mathrm{M}=\mathrm{Fe}, \mathrm{Co}$ [67]. However, a coordinating counteranion i.e. halide, should accompany the imidazole (in)um salt.

The structure of $\mathbf{1 2}$ is shown in Figure 3.

The presence of three types of ligands that can be replaced using different reaction types (e.g. chloride by salt metathesis, bis(silylamide) by further aminolysis and NHC by substitution with neutral 2 electron donors) adds to the versatility and value of the three-coordinate complexes in accessing new 3- or higher-coordinate species of $\mathrm{Fe}$ and Co under mild conditions. Selected aminolysis possibilities for the iron complexes are shown in Scheme 11 [64]; the structures of complexes 13, 14, 17-19 are given in Figures 4-8, respectively; analogous reactivity has been described for Co [65, 67]. 
<smiles>CCCCCOC1N(P)CCN1PO[SnH2]</smiles>

19

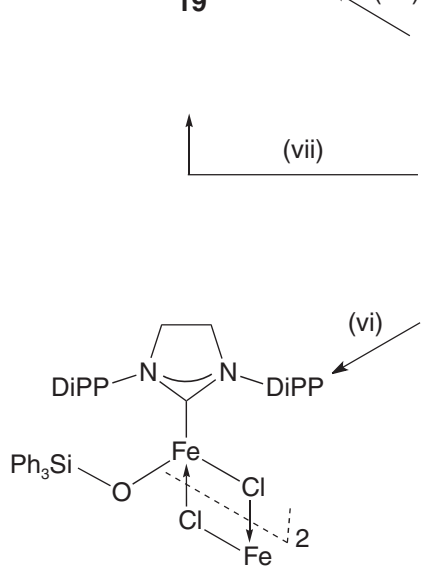

18

(vi)<smiles>CPN1CCN(P)N=C1C</smiles><smiles>CC(C)c1cccc(C(C)C)c1NO</smiles>

(i) (ii)

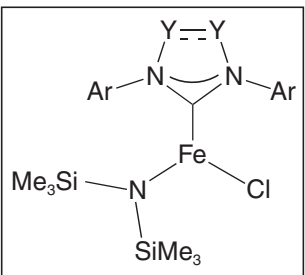

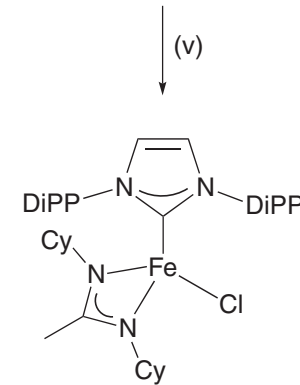

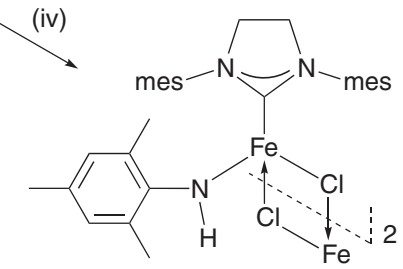

16

17

Scheme 11

Representative aminolysis reactions of 3-coordinate $\left[\mathrm{Fe}(\mathrm{NHC})\left\{\mathrm{N}\left(\mathrm{SiMe}_{3}\right)_{2}\right\} \mathrm{Cl}\right]$ complexes. Reagents and conditions: (i) 1 equiv. DiPPNH $\mathrm{in}_{2}$ octane, reflux for $5 \mathrm{~min}$; (ii) 1 equiv. DiPPNH $\mathrm{N}_{2}$ in toluene, room temp., $5 \mathrm{~h}$; (iii) 1 or 2 equiv. DiPPNHLi in ether, $-78^{\circ} \mathrm{C}$ to room temp., $5 \mathrm{~h}$ or 2 equiv. $\mathrm{DiPPNH}_{2}$ in ether, room temp., $12 \mathrm{~h}$; (iv) 1 equiv. mesNH $\mathrm{H}_{2}$ in toluene; (v) $N, N^{\prime}$-di-cyclohexyl-acetamidine, toluene $100^{\circ} \mathrm{C}, 1 \mathrm{~h}$; (vi) 1 equiv. $\mathrm{Ph}_{3} \mathrm{SiOH}$ in toluene, room temp.; (vii) 2 equiv. $\mathrm{Ph}_{3} \mathrm{SiOTl}$ in toluene, room temp., $24 \mathrm{~h}$; (viii) 2 equiv. $\mathrm{Ph}_{3} \mathrm{SiOH}$ in toluene $100^{\circ} \mathrm{C}, 1 \mathrm{~h}$.

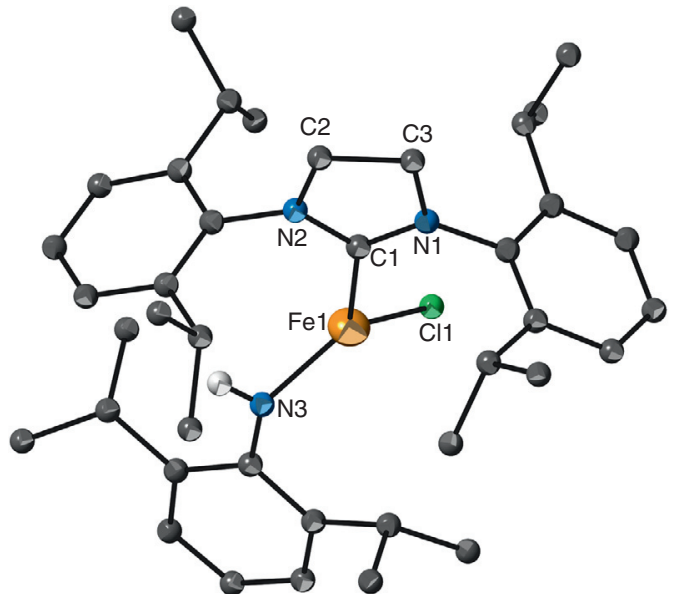

Figure 4

The structure of the $\mathrm{Fe}^{\mathrm{II}}$ complex 13. H-atoms (except the one at the anilido $\mathrm{N}$ ) are omitted.

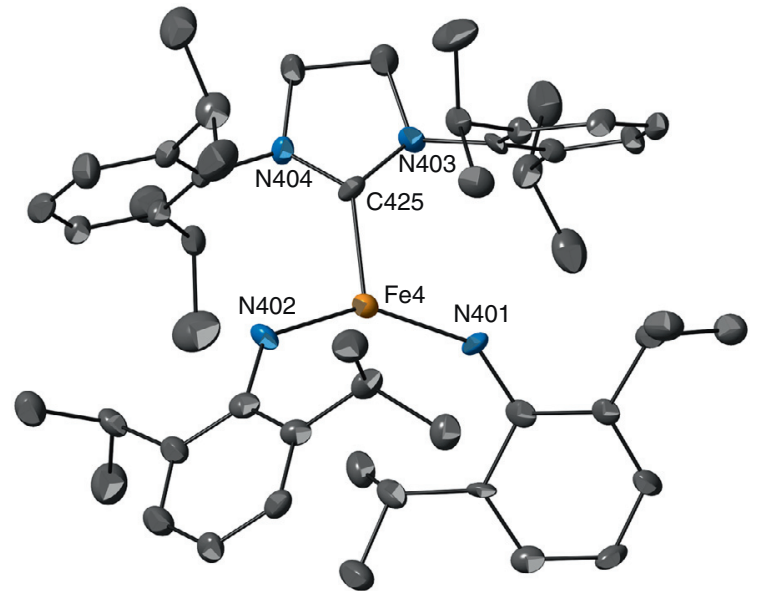

Figure 5

The structure of the $\mathrm{Fe}^{\mathrm{II}}$ complex 14. One of the four molecules found in the asymmetric unit is shown. All $\mathrm{H}$ atoms are omitted. 


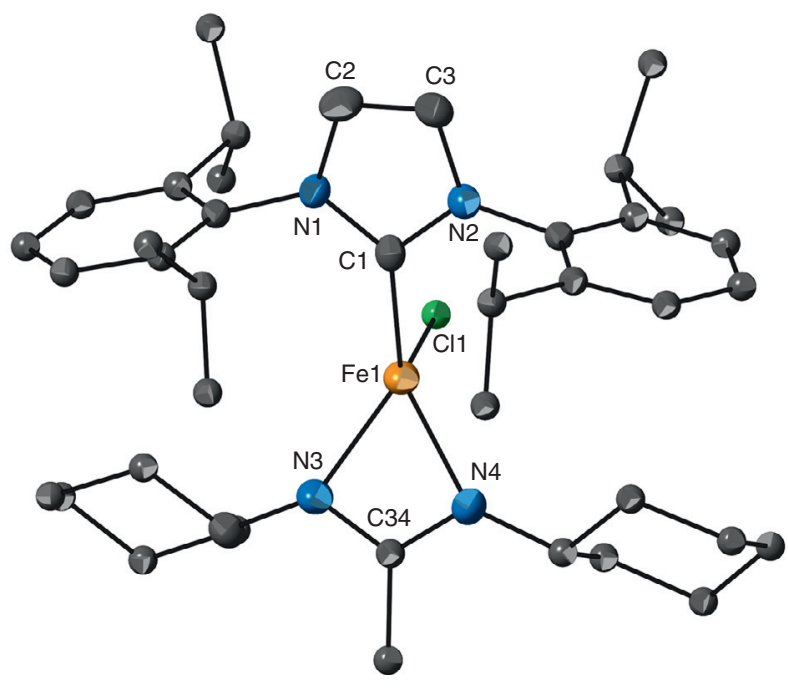

Figure 6

The structure of the $\mathrm{Fe}^{\mathrm{II}}$ complex 17. All $\mathrm{H}$ atoms are omitted.

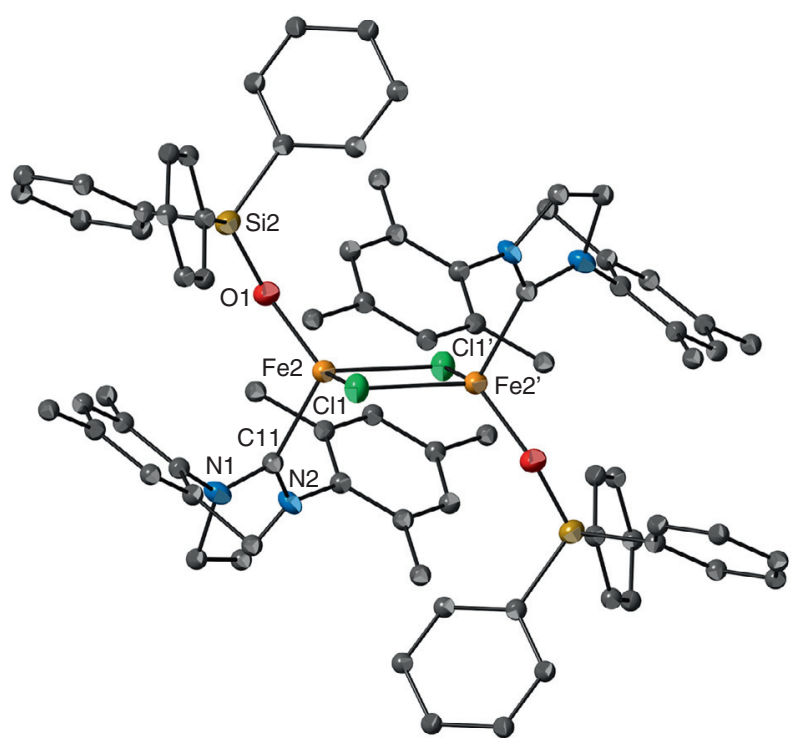

Figure 7

The dinuclear $\mathrm{Fe}^{\mathrm{II}}$ complex 18. All $\mathrm{H}$ atoms are omitted.

It can be concluded that the nature of the products obtained is dependent on the bulk of the ligands at Fe. In this respect, the sterics of the bis(trimethylsilylamide) ligand promote mononuclear 3-coordinate structures (9-12). Mesitylanilido- and triphenylsilyloxo-chlorido species $\mathbf{1 6}$ and 18, respectively, dimerize via chlorido bridge formation, while the 3-coordinate DiPPanilido-chlorido derivative 13, that was prepared under carefully controlled conditions in

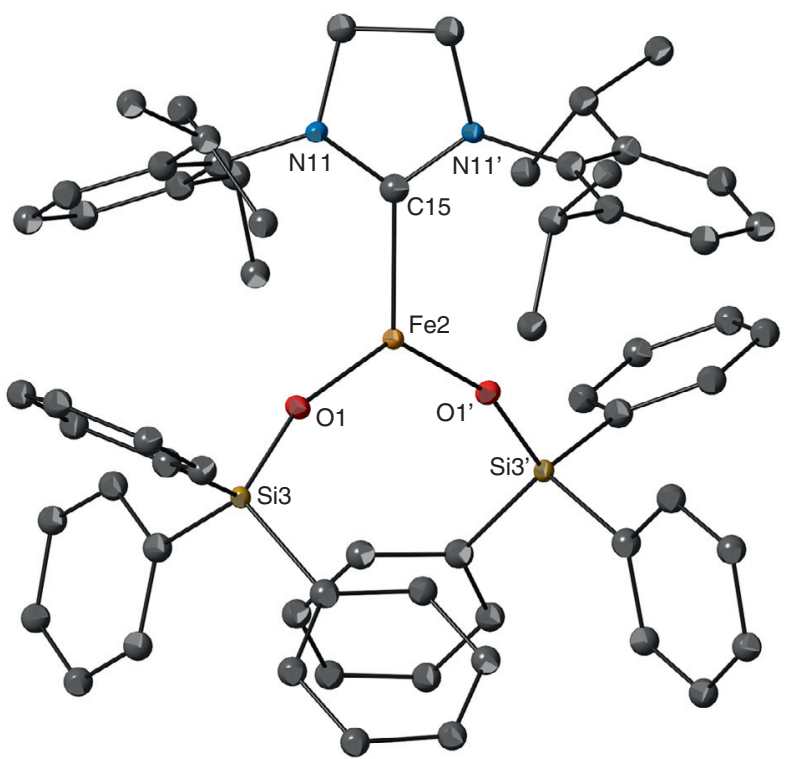

Figure 8

The structure of the $\mathrm{Fe}^{\mathrm{II}}$ complex 19. One of the two molecules found in the asymmetric unit is shown.

octane, easily conproportionates in polar solvents by ligand redistribution to form the thermodynamically more stable mononuclear 3-coordinate bis(anilido) species $\mathbf{1 4}$ and $\mathbf{1 5}$. Conproportionation has been observed in the reaction of $\mathbf{1 0}$ with thallium triphenylsiloxide. It may be that conproportionation is favoured with the combination on the metal of the bulkiest co-ligands; $\mathrm{LiN}\left(\mathrm{SiMe}_{3}\right)_{2}$ and $\mathrm{TIN}\left(\mathrm{SiMe}_{3}\right)_{2}$ may be leaving groups in these cases.

The isoelectronic relationship between amido and alkyl ligands guided efforts to prepare 3-coordinate di-alkyls and chlorido-alkyls with the bulky (S)IPr and (S)IMes as co-ligands. For $\mathrm{Fe}$, simple salt metathesis reactions using $\mathrm{FeCl}_{2}$ and $\mathrm{MgR}_{2}(\mathrm{THF})_{2}\left(\mathrm{R}=\mathrm{CH}_{2} \mathrm{SiMe}_{3}, \mathrm{CH}_{2} \mathrm{CMe}_{2} \mathrm{Ph}\right.$, $\mathrm{CH}_{2} \mathrm{Ph}$, mesityl), in the presence of IPr or SIPr in THF/dioxane was the method of choice. The alkylation was sequential (except for $\mathrm{R}=\mathrm{Mes}$ ); thus, adjustment of the stoichiometry led to either chlorido-alkyls or di-alkyls [68]. Remarkably, the chlorido-alkyls are mononuclear species (Scheme 12). The underligated complexes 20, 23, 26, 31 and $\mathbf{3 2}$ have been previously reported by us [66-68]; all other complexes shown in Scheme 12 are new. The complex [Fe(NHC) $\left.\mathrm{Mes}_{2}\right]$, where $\mathrm{NHC}=N, N$ '-diisopropyl-imidazol-2-ylidene, was reported simultaneously with our work [69]. The thermally stable 12 valence electron dialkyl complexes undergo IPr or (S)IPr substitution by (S)IMes to give the analogous 3-coordinate complexes (one example, 29, is shown in Scheme 12). The mechanism of the 


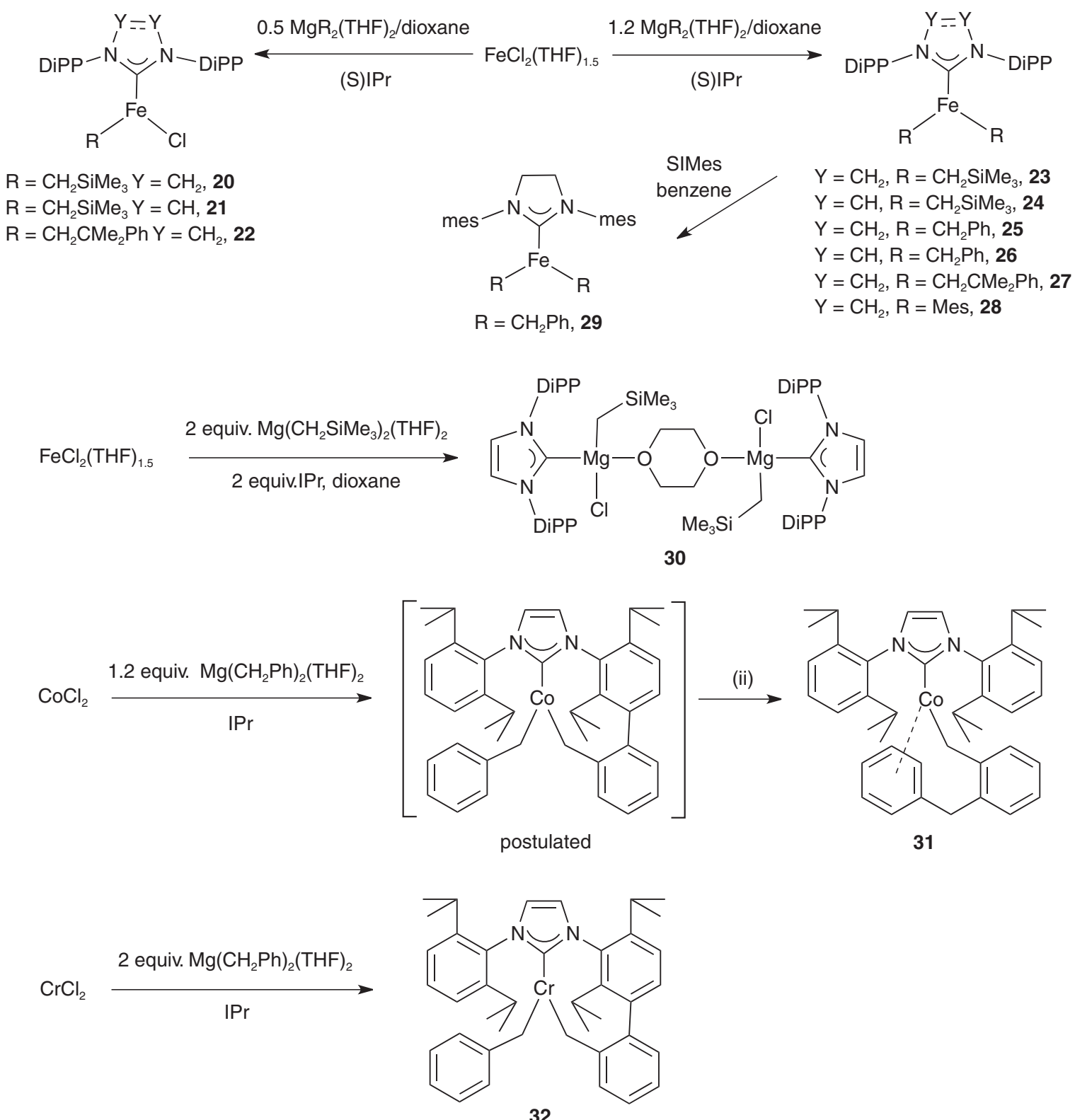

Scheme 12

Synthetic transformations leading to 3-coordinate, underligated chlorido-alkyl and di-alkyl iron, chlorido-alkyl magnesium, alkyl cobalt and dibenzyl chromium complexes.

substitution (associative versus dissociative) has not yet been clarified.

An insight into the speciation and the nature of the $\mathrm{Mg}$ alkylating agent was gained by carrying out the alkylation of $\mathrm{FeCl}_{2}$ with 2 equiv. of $\mathrm{Mg}\left(\mathrm{CH}_{2} \mathrm{SiMe}_{3}\right)_{2}(\mathrm{THF})_{2}$ and 2 equiv. IPr, and fractionally crystallizing the reaction products. After 24, the magnesium complex $\mathbf{3 0}$ was isolated as colourless crystals from pentane containing a few drops of dioxane. It is plausible that $\mathbf{3 1}$ could be accessible from the reaction of the corresponding Grignard reagent with IPr in the presence of dioxane. The structures of the underligated complexes 21, 22, 24, 25, 27-30 are shown in Figures 9-16, respectively.

On attempting the preparation of the Co analogue of $\mathbf{2 6}$, i.e. $\left[\mathrm{Co}(\mathrm{IPr})\left(\mathrm{CH}_{2} \mathrm{Ph}\right)_{2}\right]$, an unprecedented $\mathrm{C}-\mathrm{H}$ activation/ coupling reaction occurred between the two benzyl ligands at the coordination sphere of the postulated intermediate [Co(IPr) $\left.\left(\mathrm{CH}_{2} \mathrm{Ph}\right)_{2}\right]$ to give eventually 31 that features the new aryl-substituted, anionic, benzyl $8 \mathrm{e}^{-}$donor ligand 

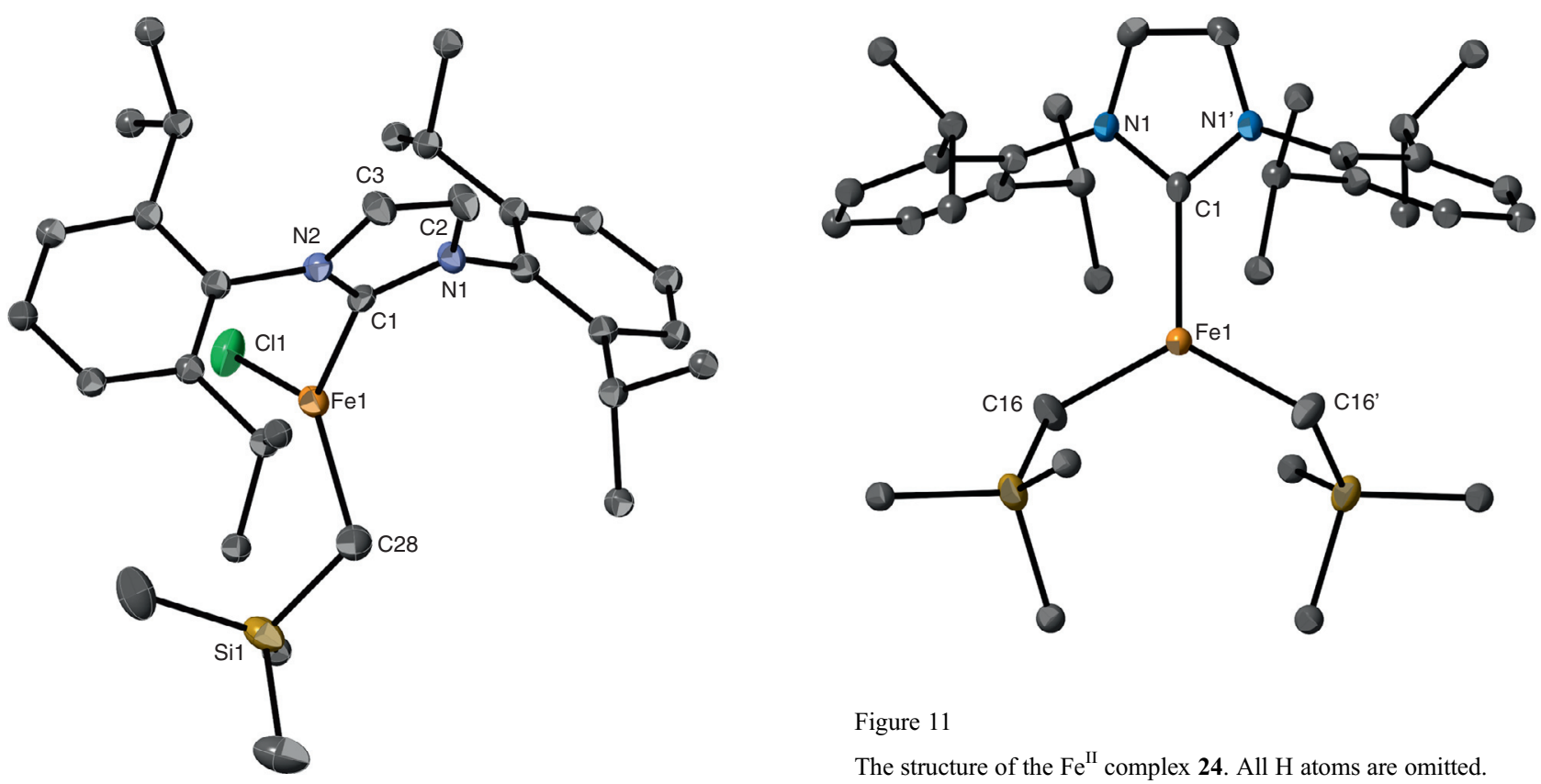

Figure 9

The structure of the Fe ${ }^{\mathrm{II}}$ complex 21. All $\mathrm{H}$ atoms are omitted.

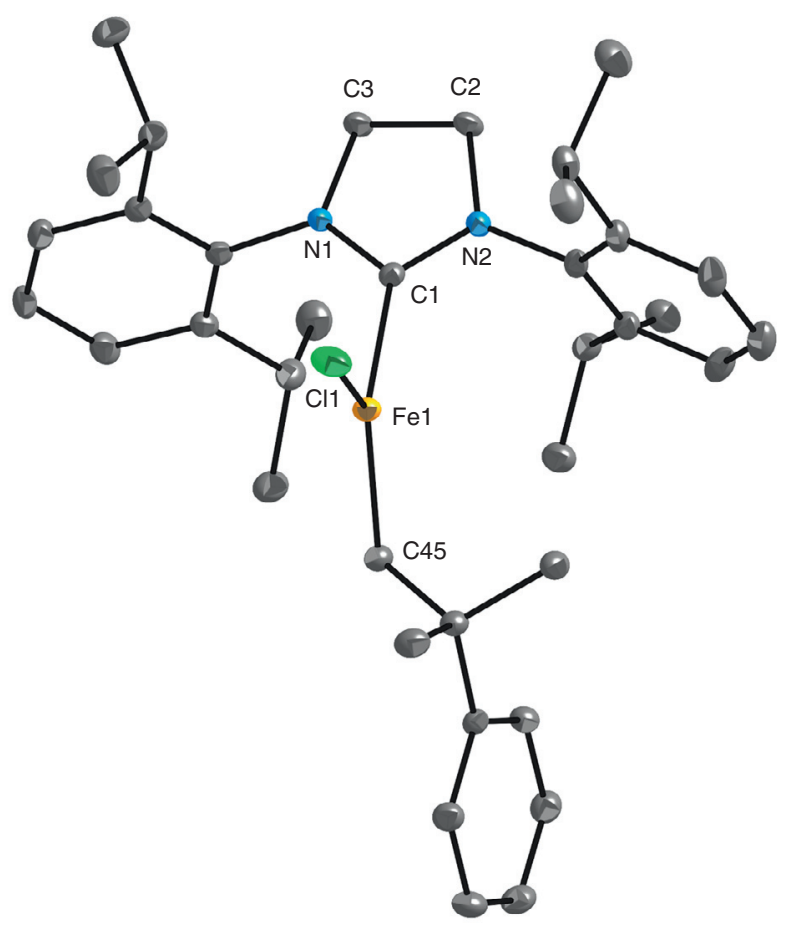

Figure 11

The structure of the Fe $\mathrm{F}^{\mathrm{II}}$ complex 24. All $\mathrm{H}$ atoms are omitted.

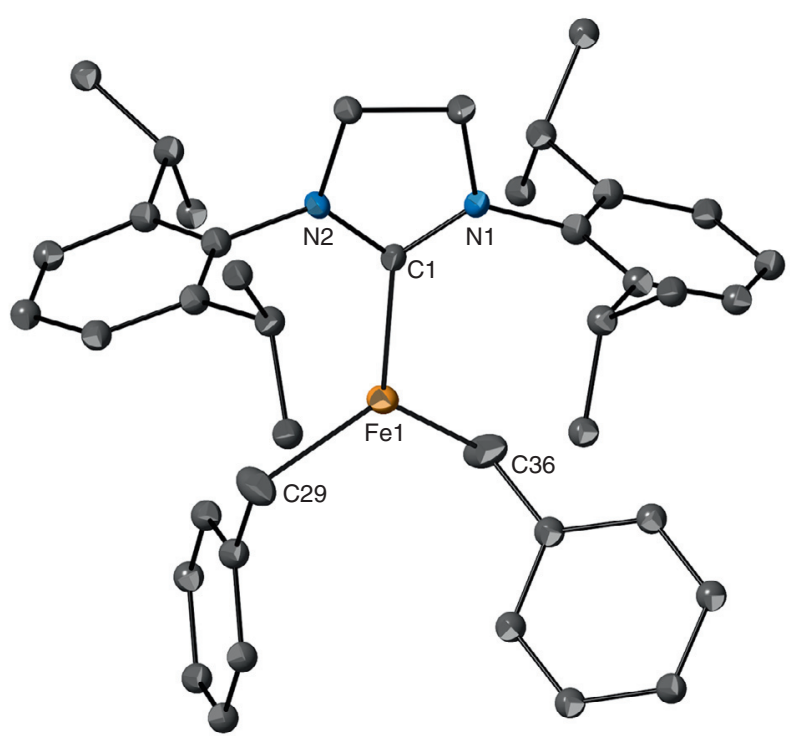

Figure 12

The structure of the bis(benzyl) $\mathrm{Fe}^{\mathrm{II}}$ complex 25. All H atoms are omitted.

Figure 10

The structure of the $\mathrm{Fe}^{\mathrm{II}}$ complex 22. All $\mathrm{H}$ atoms are omitted.

(arene $6+$ benzyl 2) [66]. In contrast, the introduction of $\mathrm{CH}_{2} \mathrm{SiMe}_{3}$ occurred smoothly, giving $\mathrm{Co}$ dialkyl complexes analogous to $\mathbf{2 4}$ [70].
The activation of $\mathrm{C}-\mathrm{H}$ bonds can proceed by mechanistically distinct pathways with metals from across the periodic table. Low oxidation state 'underligated' species may participate in $\mathrm{C}$-H activation via oxidative-addition, in higher oxidation state centres via $\sigma$-bond metathesis and in multiple-bonded species via 1,2-concerted additions or hydrogen atom transfers. One distinctive aspect of the 


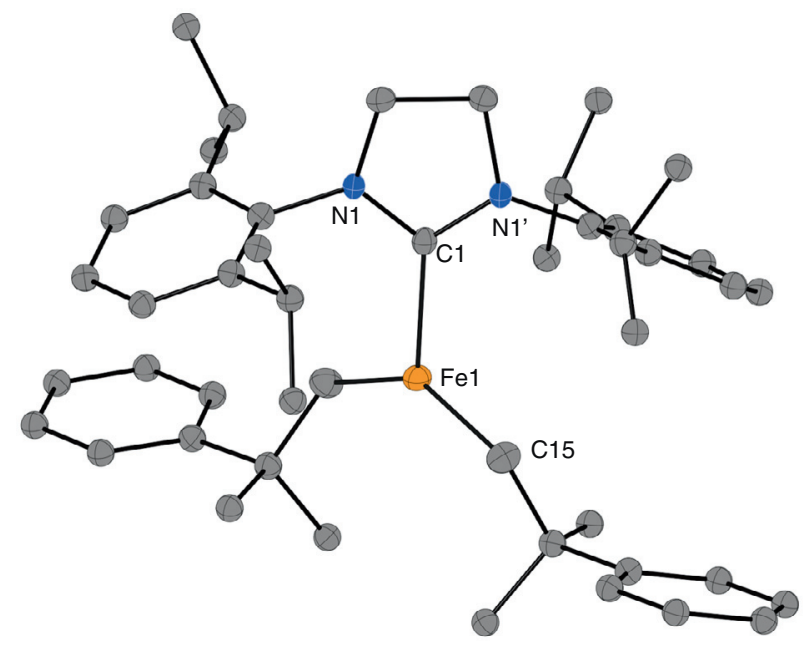

Figure 13

The structure of the $\mathrm{Fe}^{\mathrm{II}}$ complex 27. All $\mathrm{H}$ atoms are omitted.

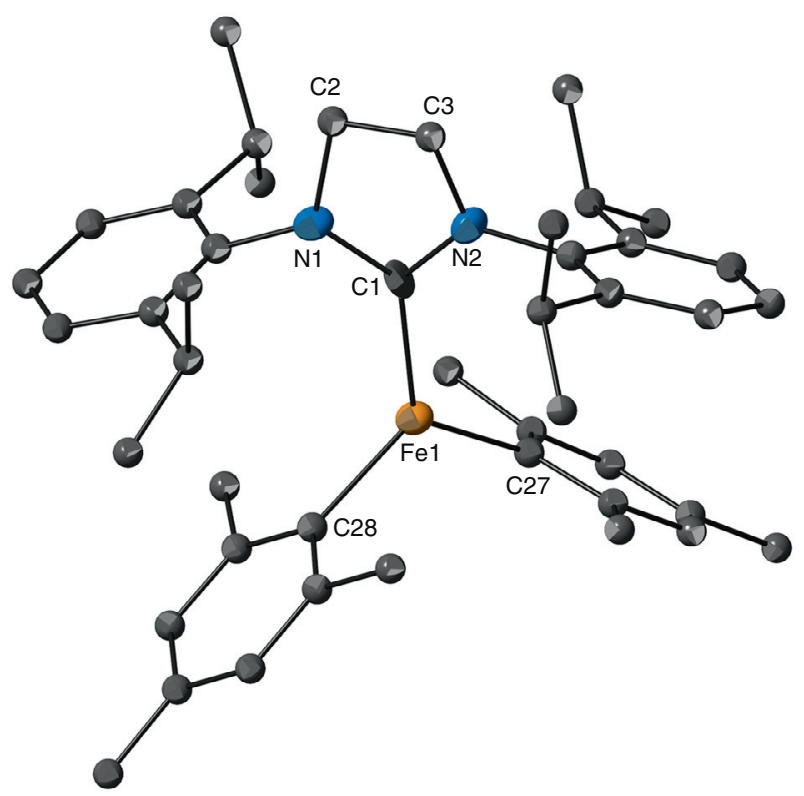

Figure 14

The structure of the Fe $\mathrm{FI}^{\mathrm{II}}$ complex 28. All $\mathrm{H}$ atoms are omitted.

'underligated' $3 d$-complexes is the presence of energetically close, usually open-shell electronic structure(s) with different spin states that may be variable during reactions, potentially promoting diverse $\mathrm{C}-\mathrm{H}$ activation mechanisms, some of them of bioinorganic relevance.

The synthesis of 3-coordinate $\mathrm{Cr}$ organometallics e.g. 32 (Scheme 12) may provide models for organometallic species

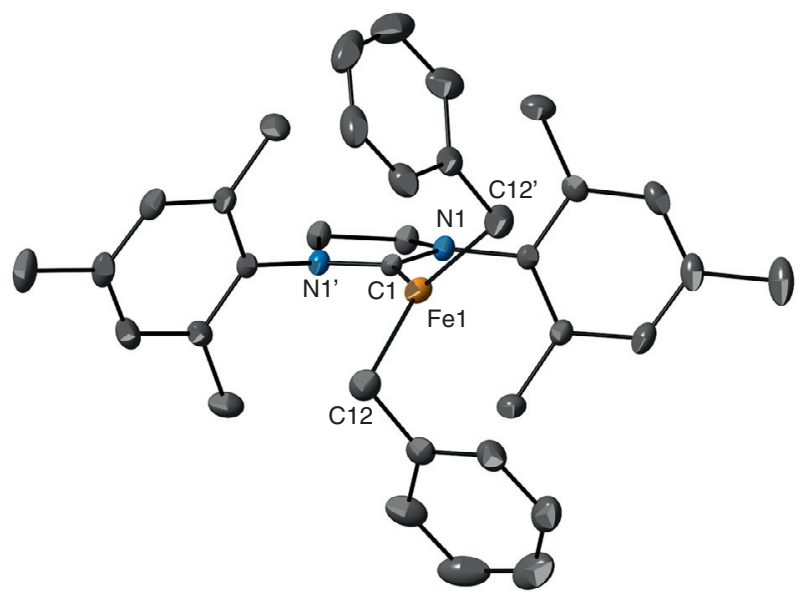

Figure 15

The structure of the bis(benzyl) $\mathrm{Fe}^{\mathrm{II}}$ complex 29. All $\mathrm{H}$ atoms are omitted.

involved in Cr-catalyzed C-C bond formation reactions [71]. The remarkable structural feature of the 10 valence electron complex 32 is the non-sterically induced severe angular distorsion away form the usual $\mathrm{sp}^{3}$ angle at the benzyl carbon atoms $\left(97.9(2)^{\circ}\right.$ and $\left.76.6(2)^{\circ}\right)$, which led to theoretical investigations and the conclusion that "Polarization-Induced Metal-Arene" interactions of a new type were at work (Fig. 17). The energy of this interaction has been calculated to be $c a .50 \mathrm{~kJ} / \mathrm{mol}$ [71].

The observation of structural effects attributable to weak energetic interactions may be possible due to the sterically open coordination sphere and the weak 3-coordinate ligand field. With respect to ethylene and alkene oligomerization, organometallic species like $\left[\mathrm{Cr}(\mathrm{IPr})\left(\mathrm{CH}_{2} \mathrm{Ph}\right)_{2}\right]$ raise interest for the following reasons:

- they can be considered as models of precursors to catalytically active species;

- they can show potential for activator-free oligomerization (since both $\mathrm{Cr}-\mathrm{C}$ carbon bonds and coordinative unsaturation are already present features);

- they may provide useful reagents for the Cr immobilization and creation of novel organometallics of catalytic relevance on supports.

The study of the organometallic chemistry of these simple systems in solution under catalytic conditions by XAS techniques should be particularly interesting. The strategy of using bulky NHC for the stabilization of 'underligated' $3 \mathrm{~d}$ metal centres has been further developed recently by using the strongly $\sigma$-donating and $\pi$-accepting cAAC ligands $[72,73]$. 


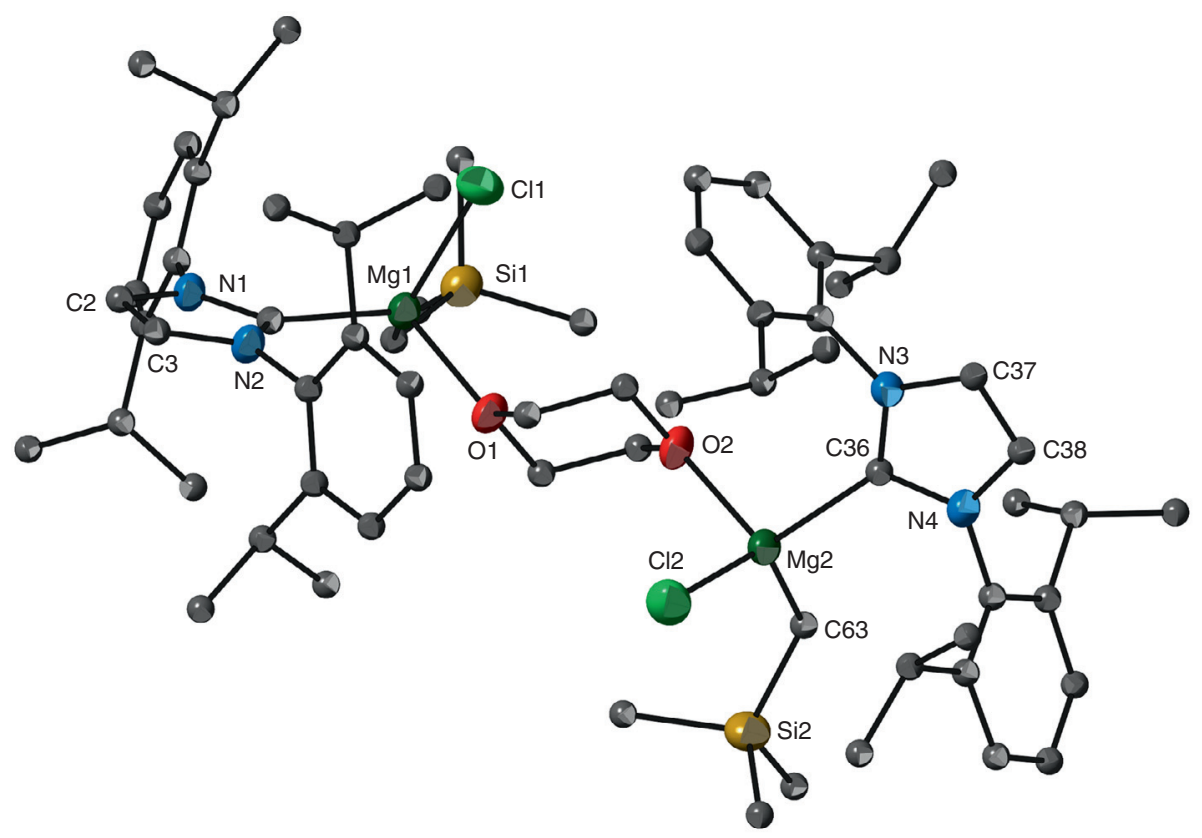

Figure 16

The structure of the dinuclear $\mathrm{Mg}$ complex $\mathbf{3 0}$. All $\mathrm{H}$ atoms are omitted.

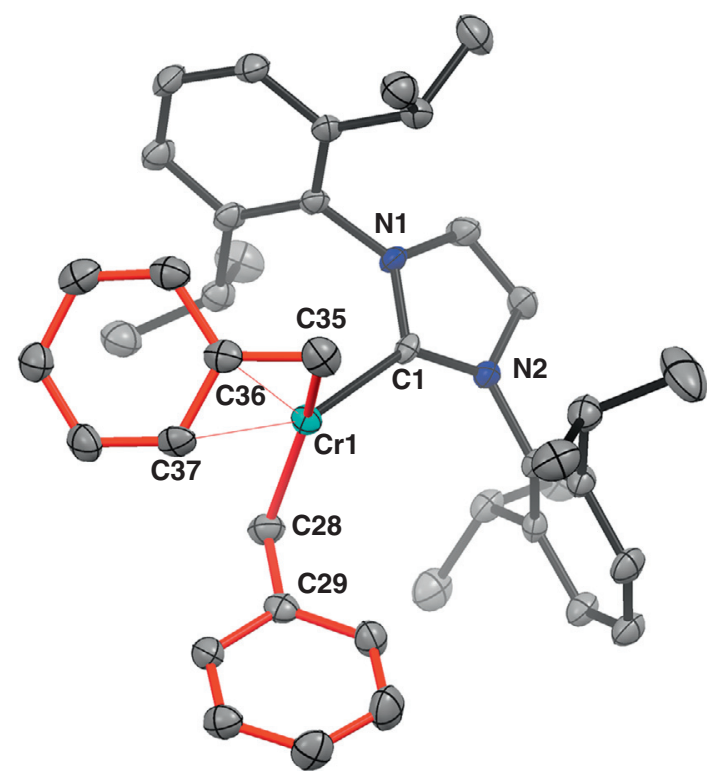

Figure 17

Polarization-induced metal-arene interactions operating in the 3-coordinate complex $\left[\mathrm{Cr}(\mathrm{IPr})\left(\mathrm{CH}_{2} \mathrm{Ph}\right)_{2}\right](\mathbf{3 2})$. Reprinted from [71]. Copyright American Chemical Society.

In conclusion, research on 'underligated' transition metal complexes opens new dimensions in molecular inorganic chemistry, leading:
- to fundamental advances in the understanding of bonding and reactivity theory,

- to applications in homogeneous and heterogeneous catalysis,

- to the exploitation of electronic and physical properties for the manufacture of useful devices [74].

It is expected to further broaden the scope and applications of 'base metals' [75].

\section{ACKNOWLEDGMENTS}

We are grateful to the coworkers and collaborators cited in the references and we thank Dr N. Stylianides and Dr R. Pattacini for assistance in solving the crystal structures of 12, 18 and 13, 24, respectively, and Dr. L. Karmazin and Miss C. Bailly (Service de Radiocristallographie, UdS) for the determination of the crystal structures of 17, 21, 24, 25, 29 and 30. The USIAS, CNRS, Université de Strasbourg, Région Alsace and Communauté Urbaine de Strasbourg are acknowledged for the award of fellowships and a Gutenberg Excellence Chair (2010-11) to AAD. We gratefully thank the CNRS, the MESR (Paris) and IFP Energies nouvelles for support.

\section{REFERENCES}

1 Braunstein P. (2004) J. Organomet. Chem. 689, 3953.

2 Speiser F., Braunstein P., Saussine L. (2005) Acc. Chem. Res. 38, 784 
3 Burridge E. (2008) Chemical Profile: Alpha Olefins, ICIS Chemical Business.

4 Lappin G.R., Sauer J.D. (eds) (1989) Alphaolefins Applications Handbook, Marcel Decker Inc., Berkeley, CA.

5 Vogt D. (2000) Oligomerization of ethylene to higher linear alpha olefins, in Applied homogeneous catalysis with organometallic compounds, Cornils B., Hermann W.A. (eds), Wiley-VCH, Weinheim, pp. 245-258.

6 Weissermel K., Arpe H.J. (2003) Olefins in Industrial Organic Chemistry, 4th edition, Weissermel K., Arpe H.J. (eds), Wiley VCH, Weinheim, pp. 63-89.

7 Bjacek P. (2003) Petrochemical prospects, Oil \& Gas Journal, Dec 15, p. 50.

8 Nakamura D.N. (2007) Ethylene report, Oil \& Gas Journal, July 16, p. 46.

9 Forestière A., Olivier-Bourbigou H., Saussine L. (2009) Oil Gas Sci. Technol. 64, 649.

10 Olivier-Bourbigou H., Forestière A., Saussine L., Magna L., Favre F., Hugues F. (2010) Oil Gas Eur. Mag. 36, 97.

11 Belov G.P., Matkovsky P.E. (2010) Pet. Chem. 50, 283.

12 Keim W. (2013) Angew. Chem. Int. Ed. 52, 12492.

13 Breuil P.-A.R., Magna L., Olivier-Bourbigou H. (2015) Catal. Lett. 145, 173.

14 Britovsek G.J.P., McGuinness D.S., Wierenga T., Young C. (2015) ACS Catal. 5, 7, 4152-4166.

15 Delferro M., Marks T.J. (2011) Chem. Rev. 111, 2450.

16 McGuinness D.S. (2011) Chem. Rev. 111, 2321.

17 Agapie T. (2011) Coord. Chem. Rev. 255, 861.

18 van Leeuwen P.W.N.M., Clément N.D., Tschan M.J.-L. (2011) Coord. Chem. Rev. 255, 1499.

19 Bianchini C., Giambastiani G., Luconi L., Meli A. (2010) Coord. Chem. Rev. 254, 431, and references cited therein.

20 Braunstein P., Matt D., Mathey F., Thavard D. (1978) J. Chem. Res. Synop. 232.

21 Braunstein P., Matt D., Mathey F., Thavard D. (1978) J. Chem. Res. Miniprint 3041.

22 Jeffrey J.C., Rauchfuss T.B. (1979) Inorg. Chem. 18, 2658.

23 Braunstein P., Naud F. (2001) Angew. Chem. Int. Ed. 40, 680.

24 Braunstein P., Matt D., Dusausoy Y. (1983) Inorg. Chem. 22, 2043.

25 Bouaoud S.-E., Braunstein P., Grandjean D., Matt D., Nobel D. (1986) Inorg. Chem. 25, 3765.

26 Braunstein P. (2006) Chem. Rev. 106, 134.

27 Keim W., Kowaldt F.H., Goddard R., Krüger C. (1978) Angew. Chem. Int. Ed. 17, 466.

28 Beach D.L., Harrison J.J. (1980) US Patent 4,293,502, (to Gulf Research).

29 Keim W., Behr A., Gruber B., Hoffmann B., Kowaldt F.H., Kürschner U., Limbäcker B., Sistig F.P. (1986) Organometallics 5, 2356.

30 Keim W. (1990) Angew. Chem. Int. Ed. Engl. 29, 235.

31 Pietsch J., Braunstein P., Chauvin Y. (1998) New J. Chem. 22, 467.

32 Klabunde U., Ittel S.D. (1987) J. Mol. Catal. 41, 123.

33 Klabunde U., Mühlhaupt R., Herskowitz T., Janowicz A.H., Calabrese J., Ittel S.D. (1987) J. Polym. Sci. Polym. Chem. 25, 1989.
34 Keim W. (1987) New J. Chem. 11, 531

35 Soula R., Broyer J.P., Llauro M.F., Tomov A., Spitz R., Claverie J., Drujon X., Malinge J., Saudemont T. (2001) Macromolecules 8, 2438.

36 Keim W. (1989) J. Mol. Catal. 52, 19.

37 Kuhn P., Sémeril D., Matt D., Chetcuti M.J., Lutz P. (2007) Dalton Trans. 515.

38 Pietsch J., Braunstein P., Chauvin Y. (1998) New J. Chem 467.

39 Heinicke J., Koesling M., Brüll R., Keim W., Pritzkow H. (2000) Eur. J. Inorg. Chem. 299.

40 Heinicke J., He M., Dal A., Klein H.F., Hetche O., Keim W., Flörke U., Haupt H.J. (2000) Eur. J. Inorg. Chem. 431.

41 Heinicke J., Köhler M., Peulecke N., He M., Kindermann M.K., Keim W., Fink G. (2003) Chem.-Eur. J. 9, 6093.

42 Heinicke J., Köhler M., Peulecke N., Keim W. (2004) J. Catal. 225, 16.

43 Heinicke J., Köhler M., Peulecke N., Keim W., Jones P.G. (2004) Z. Anorg. Allg. Chem. 630, 1181.

44 Heinicke J., Köhler M., Peulecke N., Kindermann M.K., Keim W., Köckerling M. (2005) Organometallics 24, 344.

45 Braunstein P., Chauvin Y., Mercier S., Saussine L. (2005) C. $R$. Chim. 8, 31.

46 Keim W. (2013) Angew. Chem. Int. Ed. 52, 12492.

47 Braunstein P., Chauvin Y., Mercier S., Saussine L., De Cian A., Fischer J. (1994) J. Chem. Soc. Chem. Commun. 2203.

48 Kermagoret A., Braunstein P. (2008) Dalton Trans. 822.

49 Hasanayn F., Achord P., Braunstein P., Magnier H.J., Krogh-Jespersen K., Goldman A.S. (2012) Organometallics 31, 4680 .

50 Braunstein P., Matt D., Nobel D. (1988) Chem. Rev. 88, 747.

51 Braunstein P., Matt D., Nobel D. (1988) J. Am. Chem. Soc. 110, 3207.

52 Braunstein P., Nobel D. (1989) Chem. Rev. 89, 1927.

53 Zhang S., Pattacini R., Braunstein P. (2014) in Advances in Organometallic Chemistry and Catalysis: The Silver/Gold Jubilee International Conference on Organometallic Chemistry Celebratory Book, Pombeiro A.J.L. (ed.), John Wiley \& Sons, Chapter 14.

54 Kermagoret A., Pattacini R., Chavez Vasquez P., Rogez G., Welter R., Braunstein P. (2007) Angew. Chem. Int. Ed. 46, 6438. In this paper, a pressure much higher than actually required was indicated.

55 Chavez Vasquez P., Guerrero Rios I., Kermagoret A., Pattacini R., Meli A., Bianchini C., Giambastiani G., Braunstein P. (2009) Organometallics 28, 1776.

56 Flapper J., Kooijman H., Lutz M., Spek A.L., van Leeuwen P. W.N.M., Elsevier C.J., Kamer P.C.J. (2009) Organometallics 28, 3272 .

57 Zhang J., Teo P., Pattacini R., Kermagoret A., Welter R., Rogez G., Hor T.S.A., Braunstein P. (2010) Angew. Chem. Int. Ed. 49, 4443.

58 Kayser L., Pattacini R., Rogez G., Braunstein P. (2010) Chem. Commun. 46, 6461.

59 Hameury S., Kayser L., Pattacini R., Rogez G., Wernsdorfer W., Braunstein P. (2013) Dalton Trans. 42, 5013.

60 Massard A., Rogez G., Braunstein P. (2014) Dalton Trans. 43, 42.

61 Hameury S., Kayser L., Pattacini R., Rosa P., Barra A.-L., Braunstein P. (2015) ChemPlusChem. 80, 1312. 
62 Buchwalter P., Rosé J., Braunstein P. (2015) Chem. Rev. 115, 28.

63 Braunstein P. (2015) Chem. Rec. 15, 1132-1136.

64 Ni C., Power P. (2010) Struct. Bond. 136, 59-111.

65 Danopoulos A.A., Braunstein P., Stylianides N., Wesolek M. (2011) Organometallics 30, 6514.

66 Danopoulos A.A., Braunstein P. (2013) Dalton Trans. 42, 7276.

67 Danopoulos A.A., manuscript in preparation.

68 Danopoulos A.A., Braunstein P., Wesolek M., Monakhov K.Yu., Rabu P., Robert V. (2012) Organometallics 31, 4102.

69 Xiang L., Xiao J., Deng L. (2011) Organometallics 30, 2018.

70 Przyojski J.A., Arman H.D., Tonzetich Z.J. (2012) Organometallics 32, 723.

71 Danopoulos A.A., Monakhov K.Yu., Robert V., Braunstein P., Pattacini R., Conde-Guadaño S., Hanton M., Tooze R.P. (2013) Organometallics 32, 1842.
72 Samuel P.P., Mondal K.C., Amin Sk N., Roesky H.W., Carl E., Neufeld R., Stalke D., Demeshko S., Meyer F., Ungur L., Chibotaru L.F., Christian J., Ramachandran V., van Tol J., Dalal N.S. (2014) J. Am. Chem. Soc. 136, 11964.

73 Ung G., Rittle J., Soleilhavoup M., Bertrand G., Peters J.C. (2014) Angew. Chem. Int. Ed. 53, 8427.

74 Power P.P. (2012) Chem. Rev. 112, 3482.

7575 Electronic Supplementary Information (ESI) available: X-ray crystallographic data in CIF format for CCDC reference numbers: 1413910, 12; 1413905, 13; 1413906, 14; 1413907, 17; 1413908, 18; 1413909, 19; 1413835, 21; 1413836, 22; 1413837, 24; 1413838, 25; 1413839, 27; 1413840, 28; 1413841, 29; 1413842, 30.

Manuscript submitted in July 2015 Manuscript accepted in December 2015 Published online in March 2016

Cite this article as: A.A. Danopoulos and P. Braunstein (2016). Ligand Control of the Metal Coordination Sphere: Structures, Reactivity and Catalysis, Oil Gas Sci. Technol 71, 24. 